\title{
Investigating the link between PCP signalling and ciliogenesis during zebrafish development
}

\author{
A Borovina ${ }^{1 *}$, B Ciruna ${ }^{1,2}$ \\ From First International Cilia in Development and Disease Scientific Conference (2012) \\ London, UK. 16-18 May 2012
}

Polycystic kidney disease (PKD) is characterized by dilated collecting tubules causing fluid filled cysts and enlarged kidneys. Dilated tubules can result from disrupted convergence and extension (C\&E) movements and defects in oriented cell divisions (OCD). Planar cell polarity (PCP) signalling has been implicated in PKD since defects in C\&E and OCD are both characteristic of disrupted PCP. Surprisingly, genetic studies of mutations causing PKD predominantly affect proteins that localize near cilia and basal bodies. The functional relationship between cilia and PCP signalling in the context of PKD is still poorly understood. Previous studies of PCP effector proteins suggested that PCP signalling was required for cilia formation. However, these proteins are not specific to PCP signalling and are shared with other Wnt pathways. To determine the role of a core and specific PCP regulator on ciliogenesis, we examined maternal-zygotic (MZ) vangl2 zebrafish mutants. Analysis of MZvangl2 mutants revealed that PCP is not required for cilia formation but is required for the posterior tilting and posterior positioning of motile cilia. To determine whether cilia were required to establish cell polarity, we generated MZift 88 mutants where ciliogenesis is completely abolished. MZift 88 mutants have normal C\&E movements, suggesting that cilia are not directly required for PCP mediated morphogenetic movements. However, we have observed defects in PCP-controlled OCD occurring during gastrulation. Remarkably, these divisions occur prior to cilia formation, suggesting a ciliaindependent role for IFT proteins in cell divisions. We are currently determining whether IFT88 regulates all OCD or just those that are PCP-controlled.

\section{Author details}

${ }^{1}$ Hospital for Sick Children, Canada. ${ }^{2}$ University of Toronto, Canada.

${ }^{1}$ Hospital for Sick Children, Canada

Full list of author information is available at the end of the article
Published: 16 November 2012

doi:10.1186/2046-2530-1-S1-022

Cite this article as: Borovina and Ciruna: Investigating the link between PCP signalling and ciliogenesis during zebrafish development. Cilia 2012 1(Suppl 1):O22.

Submit your next manuscript to BioMed Central and take full advantage of:

- Convenient online submission

- Thorough peer review

- No space constraints or color figure charges

- Immediate publication on acceptance

- Inclusion in PubMed, CAS, Scopus and Google Scholar

- Research which is freely available for redistribution

Submit your manuscript at www.biomedcentral.com/submit

\section{() Biomed Central}

